\title{
GENETIC LINKAGE MAP OF CHICKEN CHROMOSOME 1 FROM A BRAZILIAN RESOURCE POPULATION
}

\author{
Kátia Nones ${ }^{1}$; Mônica Corrêa Ledur ${ }^{3}$; Deborah Clea Ruy ${ }^{1,2}$; Erica Elias Baron ${ }^{1}$; Ana Silvia \\ Alves Meira Tavares Moura ${ }^{4}$; Luiz Lehmann Coutinho ${ }^{5 *}$ \\ ${ }^{1}$ USP/ESALQ - Programa de Pós-Graduação em Ciência Animal e Pastagens. \\ ${ }^{2}$ UnB - Faculdade de Agronomia e Medicina Veterinária, 70910-970 - Brasília, DF - Brasil. \\ ${ }_{4}^{3}$ Embrapa Suínos e Aves - BR 153, km 110 - 89700-000 - Concórdia, SC - Brasil. \\ ${ }^{4}$ UNESP/FMVZ - Depto. de Produção e Exploração Animal, 18618-000 - Botucatu, SP - Brasil. \\ ${ }^{5}$ USP/ESALQ - Depto. de Zootecnia, Lab. de Biotecnologia Animal, C.P. 09 - 13418-900 - Piracicaba, SP - Brasil. \\ *Corresponding author <llcoutin@esalq.usp.br>
}

\begin{abstract}
A genetic map provides insight into genome organization and chromosomal location of markers and genes, and is important for quantitative trait loci (QTL) mapping. The objective of this study was to use a Brazilian resource population to construct a linkage map for chicken chromosome 1. Eighty microsatellite markers were tested and 26 informative markers were typed in an experimental $\mathrm{F}_{2}$ population developed by two generations of crossbreeding between a broiler sire line and a layer line. A total of 649 $\mathrm{F}_{2}$ individuals from seven full-sib families with about $95 \mathrm{~F}_{2}$ offspring each were genotyped. Multi-locus linkage analysis resulted in a chromosome 1 map of 26 ordered markers. Locus order was in general agreement with other published linkage maps, except for two discrepancies: 1) order of loci MCW10 and MCW208 was reversed in this map relative to the Wageningen linkage map, 2) markers ADL234 and LEI68, that were mapped to the same position in Compton, East Lansing and Wageningen populations, were separated by a distance of 5.9 centimorgans in our population. The higher number of informative meioses from our population could explain these differences. This map is an important first step in our effort to map QTL in the Brazilian chicken resource population, and complements the international consensus map information.
\end{abstract}

Key words: microsatellites, poultry, mapping

\section{MAPA GENÉTICO DE LIGAÇÃO DO CROMOSSOMO 1 DA GALINHA DE UMA POPULAÇÃO BRASILEIRA}

\begin{abstract}
RESUMO: Um mapa genético proporciona o entendimento da organização do genoma e da localização cromossômica de marcadores e genes, e é importante para o mapeamento de locos controladores de características quantitativas (QTL). O objetivo deste estudo foi utilizar uma população brasileira para construir um mapa de ligação do cromossomo 1 da galinha. Oitenta marcadores microssatélites foram testados e 26 marcadores informativos foram genotipados em uma população $F_{2}$ experimental, desenvolvida em duas gerações de um cruzamento entre uma linha macho de corte e uma linhagem de postura. Foram genotipados um total de 649 indivíduos $\mathrm{F}_{2}$ de sete famílias de irmãos completos com cerca de $95 \mathrm{~F}_{2}$ cada uma. A análise de ligação Multi-locus gerou um mapa do cromossomo 1 com 26 marcadores ordenados. A ordem dos locos foi em geral semelhante àquela de outros mapas de ligação publicados, exceto por duas discrepâncias: 1) a ordem entre os marcadores MCW10 e MCW208 foi invertida no presente mapa quando comparado com o mapa de ligação de Wageningen, 2) Os marcadores ADL234 e LEI68 que foram mapeados na mesma posição nas populações de Compton, East Lansing e Wageningen foram separados por uma distância de 5,9 centimorgans na presente população. O maior número de meioses informativas desta população pode explicar esta diferença. Este mapa é o primeiro passo no esforço de mapear QTL na população brasileira o qual pode também ser usado para complementar a informação do mapa consenso internacional da galinha.
\end{abstract}

Palavras-chave: microssatélites, frango, mapeamento

\section{INTRODUCTION}

The construction of a linkage map is an important step towards our understanding of the chicken genome. It allows localization of genes and markers in chromosomes, identification of regions that control quantita- tive traits, and investigation of heritable and non-heritable components of complex traits and how they interact.

The most common markers used for genetic mapping in animals are microsatellites. These are tandem repeats of one to six nucleotides. They are easily typed by polymerase chain reaction (PCR) amplification and the 
amplicons often exhibit length polymorphisms among individuals that can be identified on automated DNA sequencers (Cheng, 1997). There are currently 2,522 loci mapped in the chicken genome, most of them are microsatellite markers (ARKdb:http://www.thearkdb.org/, 05/26/2004). Microsatellites are fairly well distributed along the genome, and the fact that they behave as codominant markers, make them ideally suited for linkage map construction.

Poultry products are important sources of high quality protein for human nutrition and knowledge of the chicken genome has the potential to generate technologies that will increase efficiency of meat and egg production. Chickens are excellent animals to study genetic and biological processes. They have short generation intervals, can produce large full sib families and possess nucleated red blood cells that allow isolation of large amounts of DNA. These points make them well suited for linkage map construction and QTL mapping (Groenen et al., 1998).

There are three recognized reference populations used to build chicken genetic maps. The first map, based on the Compton (C) population, employed about 100 markers in 18 linkage groups that contained $585 \mathrm{cM}$ (Bumstead \& Palyga, 1992). In the second map, based on the East Lansing (EL) population, 98 markers were described in 19 linkage groups that contained $590 \mathrm{cM}$ (Levin et al., 1994). The third map, based on the Wageningen (WAU) population, used 430 markers in 28 linkage groups covering $3,062 \mathrm{cM}$. This linkage map has 210 markers in common with the $\mathrm{C}$ and EL maps (Groenen et al., 1998). These three maps were integrated into one consensus linkage map by Groenen et al. (2000), and a total of 1,889 markers were mapped with a coverage of 3,800 cM. However, new markers were developed in the last few years and they are not all yet integrated to the consensus map.

A new resource population requires identification of informative markers, their correct ordering and the genetic distances between them, before QTL can be mapped. Thus, the objective of this work was to identify the most informative microsatellite markers for chromosome 1 and to construct a genetic linkage map for a Brazilian resource population developed by the Brasilian Instituition, Embrapa, designed to map QTL for production and carcass traits of chickens.

\section{MATERIAL AND METHODS}

\section{Experimental Population}

An $\mathrm{F}_{2}$ chicken population was developed by crossing a broiler male line (TT) with a layer line (CC) to generate linkage disequilibrium. This population was initiated in 1999 at Embrapa Suínos e Aves in a collaborative effort with ESALQ/USP. Seven TT males were crossed with seven $\mathrm{CC}$ females to produce $\mathrm{F}_{1}$ chickens (TC). Seven $\mathrm{F}_{1}$
TC males were crossed with three $\mathrm{F}_{1} \mathrm{TC}$ females each, comprising 21 full-sib families with about $95 \mathrm{~F}_{2}$ chicks each, totalizing 2,063 $\mathrm{F}_{2}$ offspring from 17 hatches.

The TT is a broiler male line developed by Embrapa, and has been under within line selection for improving body weight, feed conversion, retail cut yield, breast meat weight, viability, fertility, hatchability, and reducing abdominal fat. The $\mathrm{CC}$ is a White Leghorn pure line that has been selected for improving egg production, egg weight, feed conversion, hatchability, sexual maturity, fertility, viability, egg quality and reducing body weight. A detailed description of the lines was reported by Figueiredo et al. (2003a;b).

\section{Genotyping}

Genotyping was performed by PCR using microsatellite markers provided by the United States Poultry Genome Project and the Roslin Institute. The PCR reaction for each marker was carried out in a total volume of $25 \mu \mathrm{L}$. Reactions contained 60 to $100 \mathrm{ng}$ of genomic DNA extracted from blood, $4.0 \mathrm{mmol} \mathrm{L}^{-1} \mathrm{MgCl}_{2}, 50 \mathrm{mmol}$ $\mathrm{L}^{-1} \mathrm{KCl}, 10 \mathrm{mmol} \mathrm{L}{ }^{-1}$ Tris- $\mathrm{HCl}(\mathrm{pH} 8.5), 400 \mu \mathrm{M}$ of each deoxyribonucleotide, $1.5 \mathrm{U}$ Taq DNA polymerase and 5 pmol of each primer. The PCR program used was: $5 \mathrm{~min}$ at $95^{\circ} \mathrm{C}$ for initial denaturation, 30 cycles of $45 \mathrm{~s}$ at $95^{\circ} \mathrm{C}$, $45 \mathrm{~s}$ at annealing temperature $\left(50\right.$ to $\left.64^{\circ} \mathrm{C}\right)$ and $45 \mathrm{~s}$ at $72^{\circ} \mathrm{C}$, followed by a final elongation step of $10 \mathrm{~min}$ at $72^{\circ} \mathrm{C}$. Three to five markers were combined based on the fragment size and fluorescence of the PCR product. A mixture of 2.0 to $5.0 \mu \mathrm{L}$ of the PCR products was diluted $10 \mathrm{x}$. For genotyping, $2.0 \mu \mathrm{L}$ of this diluted mixture plus 7.75 $\mu \mathrm{L}$ of Tween 20 and $0.25 \mu \mathrm{L}$ of ET-ROX400 - internal size standard (Amersham Bioscience) were denatured by heating at $95^{\circ} \mathrm{C}$ for $1 \mathrm{~min}$. Genotyping was carried out on the MegaBACE automated sequencer (Amersham Bioscience) and fragment size analysis performed with the Genetic Profiler software (Amersham Bioscience). Eighty markers were tested in parental and $F_{1}$ individuals, and 26 informative markers were selected for map construction. All individual genotypes were checked manually twice. In addition, potential typing errors were rechecked for inheritance in the CRIMAP package (Green et al., 1990), using the PREPARE and CHROMPIC options, and corrected when necessary.

\section{Linkage Analysis}

Linkage analysis for chromosome 1 was performed using the CRIMAP program version 2.4 (Green et al., 1990), which uses the Kosambi function to convert recombination fractions to centimorgans $(\mathrm{cM})$ distances. Data of genotypes from three half-sib families which included seven full-sib families $\left(649 \mathrm{~F}_{2}\right.$ individuals) for 26 markers were used. Only part of the population was typed because of the high cost associated with genotyping. 
Initially, the TWO POINT option of CRIMAP was used for a two-point linkage analysis in which all 26 markers were tested against each other. This analysis was done to confirm that all markers were located in the same linkage group. The ordering of loci was obtained with the $B U I L D$ option. A pair of highly polymorphic linked loci was chosen to start to order the markers. The other loci were progressively added to the map, placed in each possible position with respect to the loci already ordered (Barker et al., 1987). The best position (order) was based on the highest log 10 likelihood. Finally, the order of different loci was checked using the FLIPS option, to look for an erroneous order. The best map was based on the highest $\log 10$ likelihood. To confirm the order, different starting pairs of loci and different order of addition of loci were tested. Finally, the CHROMPIC option was used to verify every recombination event among ordered markers and to identify errors and potential double-crossing overs. The map was drawn with the Map Chart software, version 2.1 (Voorrips, 2002).

\section{RESULTS AND DISCUSSION}

From 80 markers tested 47 were informative. Ten of them could not be used because no amplification products were obtained; 20 were not informative or were informative only in a few families, and three were inconsistent for genotyping. Twenty-six informative markers, located in regions where QTL were previously mapped, were selected for map construction (Table 1). Each marker was considered informative in each family when one $F_{1}$ parent was heterozygous and the other $F_{1}$ parent had a different genotype, allowing determination of the origin of alleles present in the $\mathrm{F}_{2}$ individuals. An example of a heterozygous $\mathrm{F}_{1}$ individual genotype is represented in Figure 1.

The linkage analysis using genotypes from 649 $\mathrm{F}_{2}$ individuals started with the TWO POINT option with
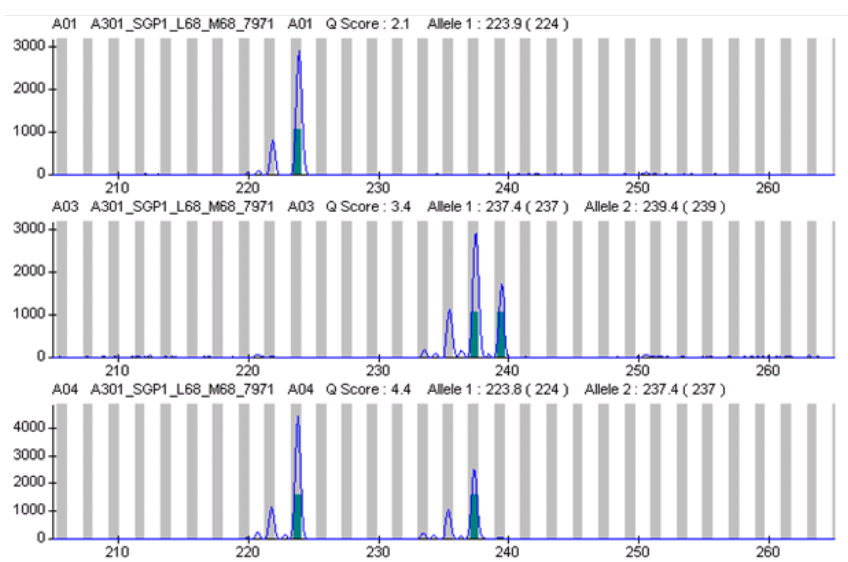

Figure 1- Genotyping image from MegaBACE sequencer showing genotype of parental individuals (a. genotype 224/224 and b. 237/239) and an informative $\mathrm{F}_{1}$ individual (c. 224/ 237) for marker LEI68.

Sci. Agric. (Piracicaba, Braz.), v.62, n.1, p.12-17, Jan./Feb. 2005 a LOD score of 3.0. Only markers MCW10 and MCW208 did not have their recombination fractions calculated relative to other markers. Based on other maps (C, EL and WAU), these two markers are located on chromosome 1, but at a large distance, of about $50 \mathrm{cM}$, from other markers used in this study. We then reduced the LOD score to 2.0 , and the recombination fraction estimated between markers MCW208 and ADL188 was 0.42 with LOD score 2.91. Considering that the recombination fraction between MCW10 and MCW208 was 0.03 with LOD score of 100.75 , we concluded that all markers were located in the same chromosome. However, more markers need to be typed in this region to reduce the distance among MCW208 and the remaining markers.

The next step was to order the loci using the BUILD option. A total of 24 loci were ordered. Markers MCW36 and ADL183 could not be ordered. Marker MCW36 and the flanking markers showed few informative meioses, and this can make it difficult to determine the order of a marker in a chromosome. As for marker ADL183, a possible explanation is the small recombination fraction between ADL183 and the next marker (LEI79). Thus, a strategy in which markers were ordered in subsets was adopted. Markers MCW36 and ADL183 were then ordered without changing the distances between adjacent markers. Loci orders were checked using the FLIPS option, to look for an erroneous order, but none was found. Finally, the CHROMPIC option was used to verify every recombination event among ordered markers. A few errors were found, the genotypes were corrected and the map re-constructed. These corrections of genotypes did not alter marker orders, only the distances between them. Map distances and recombination fractions

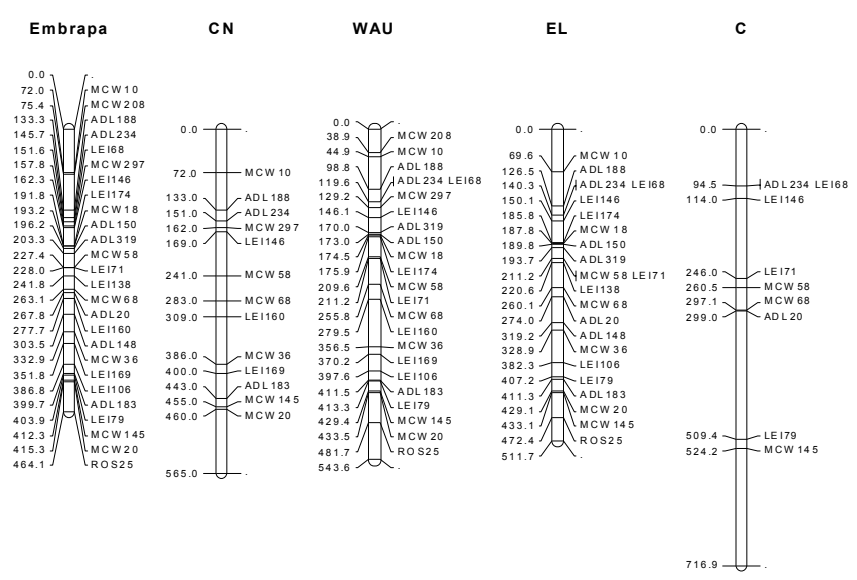

Figure 2 - Linkage maps of Embrapa population, Consensus map (CN) and Wageningen (WAU), Compton (C), East Lansing (EL) populations. Only the position of 26 markers used in this study are represented in these maps. The distances in the Embrapa map were summed over the position of marker MCW10 in the consensus map $(72 \mathrm{cM})$ to facilitate comparisons. 
are shown in Table 2. Map distances given in this paper are sex-averaged distances in $\mathrm{cM}$. The representation of the linkage map for the Embrapa population and the position of the same 26 markers in the reference populations maps are shown in Figure 2.

The linkage map covered $392 \mathrm{cM}$ from the total $565 \mathrm{cM}$ on chromosome 1 . The average marker interval was $15.68 \mathrm{cM}$, varying from 0.6 to $57.9 \mathrm{cM}$. The average polymorphic information content for this map was 0.68 , ranging from 0.37 to 0.96 (Figure 3 ). There are two regions with low information content, one at the beginning and the other at the end of the linkage map. These regions are those where we have the highest distances between markers. The information content could be improved by increasing marker density (Van Kaam et al., 1998). The information content also might influence the chances to detect QTL, but this can be overcome by typing more informative markers in these regions.

Table 1 - Genetic markers used in the linkage analysis, number of alleles and number of informative meioses.

\begin{tabular}{|c|c|c|c|}
\hline Marker & $\begin{array}{c}\text { Number } \\
\text { of } \\
\text { alleles }\end{array}$ & $\begin{array}{l}\text { Number of } \\
\text { informative } \\
\text { meioses }\end{array}$ & $\begin{array}{c}\text { Number of } \\
\text { informative meioses } \\
\text { (phase-known) }\end{array}$ \\
\hline MCW10 & 4 & 809 & 809 \\
\hline MCW208 & 3 & 909 & 421 \\
\hline ADL1 88 & 3 & 546 & 412 \\
\hline ADL234 & 4 & 803 & 803 \\
\hline LEI68 & 4 & 978 & 978 \\
\hline MCW297 & 4 & 656 & 656 \\
\hline LEI146 & 4 & 1267 & 891 \\
\hline LEI174 & 3 & 536 & 536 \\
\hline MCW18 & 4 & 1155 & 499 \\
\hline ADL150 & 4 & 1248 & 542 \\
\hline ADL319 & 2 & 726 & 444 \\
\hline MCW58 & 3 & 1083 & 595 \\
\hline LEI7 1 & 5 & 1276 & 770 \\
\hline LEI138 & 2 & 774 & 398 \\
\hline MCW68 & 5 & 995 & 689 \\
\hline ADL20 & 5 & 1142 & 1142 \\
\hline LEI1 60 & 3 & 1160 & 396 \\
\hline ADL148 & 4 & 890 & 382 \\
\hline MCW36 & 3 & 1081 & 263 \\
\hline LEI1 69 & 2 & 1112 & 0 \\
\hline LEI106 & 3 & 1008 & 620 \\
\hline ADL1 83 & 4 & 1057 & 738 \\
\hline LEI79 & 3 & 922 & 726 \\
\hline MCW 145 & 3 & 1002 & 666 \\
\hline MCW20 & 4 & 1134 & 1134 \\
\hline ROS 25 & 4 & 792 & 697 \\
\hline
\end{tabular}

In our population, the number of informative meioses varied from 536 to 1,276 , with an average of 964 (Table 1). The number of informative meioses per marker for the whole genome scan in the WAU population varied from 100 to 900, with an average of 400 in 10 full sib families with an average of $46 \mathrm{~F}_{2}$ offspring per family (Groenen et al., 1998). In the other populations, EL ( 52 offspring from a backcross population) and C (56 offspring from a backcross population), the number of informative meioses was even smaller, varying from 20 to 56 (Schmid et al., 2000). Therefore, in this study, the number of $\mathrm{F}_{2}$ individuals within each family was almost twice the number used in the WAU population. This population provides a significant number of informative meioses to construct a trustable map for QTL mapping.

When we compare our linkage map with the other chicken linkage maps (Figure 2), 14 markers out of 26 used did not have a consensus position. These markers were mapped only in EL, C or WAU populations. Markers in common with our map and the consensus map had equal order positions, but the distances between markers were smaller than in the consensus map. A possible explanation is that our population is larger and showed a higher number of informative meioses than the other populations.

There are some discrepancies between EL, C and WAU maps. For example, the order of markers ADL319, ADL150, MCW18 and LEI174 were inverted between EL and WAU populations (Figure 2). In our map, the order was equal to that of the EL map and the distances among these markers were very similar.

Here, the order of markers MCW10 and MCW208 disagreed with the order in the WAU map, the only population where marker MCW208 was mapped. To confirm this inversion, more markers need to be added to reduce the gap between marker MCW208 and other markers in our population.

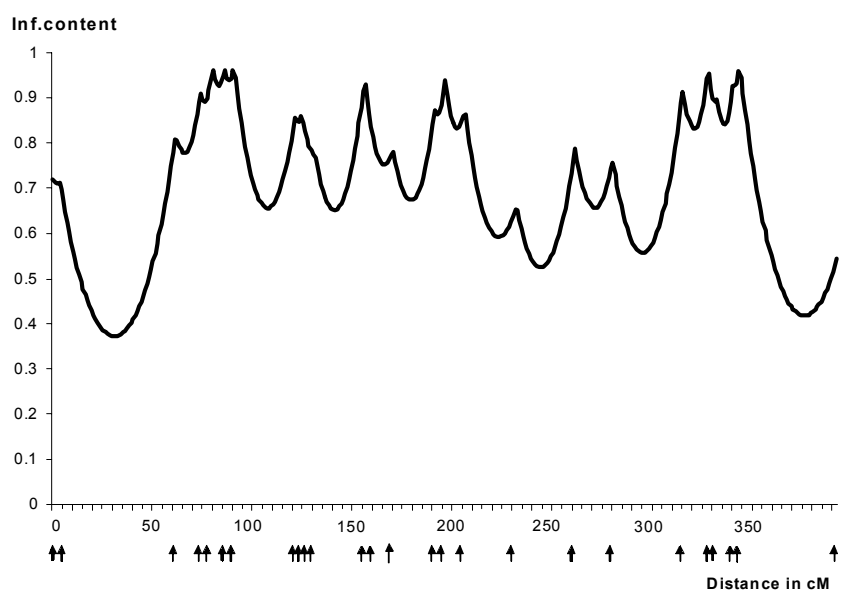

Figure 3 - Information content for chromosome 1 of Embrapa population, using all marker information simultaneously. Distances are given using the Kosambi scale for the sexaveraged map. Arrows indicate marker positions. 
Table 2 - Embrapa linkage map with the estimated Kosambi map distances (sex-averaged) and recombination fractions.

\begin{tabular}{|c|c|c|c|}
\hline Marker & Position & Interval & Recombination fraction \\
\hline \multicolumn{4}{|c|}{-..-- cM -.....-- } \\
\hline \multirow{2}{*}{ MCW 10} & 0 & & \\
\hline & & 3.4 & 0.03 \\
\hline \multirow[t]{2}{*}{ MCW208 } & 3.4 & & \\
\hline & & 57.9 & 0.42 \\
\hline \multirow{2}{*}{ ADL188 } & 61.3 & & \\
\hline & & 12.4 & 0.12 \\
\hline \multirow[t]{2}{*}{ ADL234 } & 73.7 & & \\
\hline & & 5.9 & 0.06 \\
\hline \multirow{2}{*}{ LEI68 } & 79.6 & & \\
\hline & & 6.2 & 0.06 \\
\hline \multirow[t]{2}{*}{ MCW297 } & 85.8 & & \\
\hline & & 4.5 & 0.04 \\
\hline \multirow{2}{*}{ LEI146 } & 90.3 & & \\
\hline & & 29.5 & 0.27 \\
\hline \multirow[t]{2}{*}{ LEI174 } & 119.8 & & \\
\hline & & 1.4 & 0.01 \\
\hline \multirow{2}{*}{ MCW 18} & 121.2 & & \\
\hline & & 3.0 & 0.03 \\
\hline \multirow[t]{2}{*}{ ADL150 } & 124.2 & & \\
\hline & & 7.1 & 0.07 \\
\hline \multirow{2}{*}{ ADL3 19} & 131.3 & & \\
\hline & & 24.1 & 0.22 \\
\hline \multirow[t]{2}{*}{ MCW58 } & 155.4 & & \\
\hline & & 0.6 & 0.01 \\
\hline \multirow{2}{*}{ LEI71 } & 156 & & \\
\hline & & 13.8 & 0.14 \\
\hline \multirow[t]{2}{*}{ LEI138 } & 169.8 & & \\
\hline & & 21.3 & 0.20 \\
\hline \multirow[t]{2}{*}{ MCW68 } & 191.1 & & \\
\hline & & 4.7 & 0.05 \\
\hline \multirow[t]{2}{*}{ ADL20 } & 195.8 & & \\
\hline & & 9.9 & 0.10 \\
\hline \multirow[t]{2}{*}{ LEI1 60} & 205.7 & & \\
\hline & & 25.8 & 0.24 \\
\hline \multirow[t]{2}{*}{ ADL148 } & 231.5 & & \\
\hline & & 29.4 & 0.26 \\
\hline \multirow[t]{2}{*}{ MCW36 } & 260.9 & & \\
\hline & & 18.9 & 0.18 \\
\hline \multirow[t]{2}{*}{ LEI169 } & 279.8 & & \\
\hline & & 35.0 & 0.30 \\
\hline LEI106 & 314.8 & & \\
\hline & & 12.9 & 0.13 \\
\hline ADL183 & 327.7 & & \\
\hline & & 4.2 & 0.04 \\
\hline LEI79 & 331.9 & & \\
\hline & & 8.4 & 0.08 \\
\hline MCW145 & 340.3 & & \\
\hline & & 3.0 & 0.03 \\
\hline MCW20 & 343.3 & & \\
\hline & & 48.8 & 0.38 \\
\hline ROS 25 & 392.1 & & \\
\hline
\end{tabular}

In the three reference maps ( $\mathrm{C}, \mathrm{EL}$ and WAU), markers ADL234 and LEI68 were located at the same position. In our map, a recombination fraction of 0.06 with a LOD score of 132.46, and a distance of $5.9 \mathrm{cM}$ between these markers were estimated. This probably happened because our population had a higher number of informative meioses than the other populations, which allowed detecting shorter distances between markers.

The map developed will be used for future QTL mapping studies, because it was constructed based on a large amount of information, with an average of 964 informative meioses and 623 phase-known informative meioses. This number is higher than those used in the other populations. The addition of more microsatellite markers would greatly aid in the saturation and utility of this genetic map.

\section{CONCLUSION}

The linkage map of chicken chromosome 1 described in this paper integrates markers mapped in different populations. This map is an effective tool for QTL mapping in our and other resource populations because of the large number of informative meioses obtained in this study.

\section{ACKNOWLEDGEMENTS}

To US Chicken Genome Project (Dr. Jerry Dodgson and Dr. Hans H. Cheng) and the Roslin Institute (Dr. David W. Burt) for primer donation. Financial support was provided by FAPESP, Embrapa/Prodetab, FUNCITEC and CNPq.

\section{REFERENCES}

BARKER, D.; GREEN, P.; KNOWLTON, R.; SCHUMM, J.; LANDER, E.; OLIPHANT, A.; WILLARD, H.; AKOTS, G.; BROWN, V.; GRAVIUS, T.; HELMS, C.; NELSON, C.; PARKER, C.; REDIKER, K.; RISING, M.; WATT, D.; WEIFFENBACH, B.; DONIS-KELLER, H. Genetic linkage map of human chromosome 7 with 63 DNA markers. Proceedings of National Academy of Sciences of the USA, v.84, p.8006-8010, 1987.

BUMSTEAD, N.; PALYGA, J. A preliminary linkage map of the chicken genome. Genomics, v.13, p.690-697, 1992.

CHENG, H.H. Mapping the chicken genome. Poultry Science, v.76, p.11011107, 1997.

FIGUEIREDO, E.A.P.; ROSA, P.S.; SCHEUERMANN, G.N.; JAENISCH, F.R.F.; SCHMIDT, G.S.; LEDUR, M.; BRENTANO, L.; COSTA, C.A.F. Genetic gain in body weight feed conversion and carcass traits in White Plymouth Rock broiler strain Embrapa 021. In: WORLD CONFERENCE ON ANIMAL PRODUCTION, 9.; REUNIÃO DA ASSOC. LATINOAMERICANA DE PRODUÇÃO ANIMAL, 18., Porto Alegre, 2003. Porto Alegre: WAAP; ALPA; SBZ; UFRGS, 2003a. CD-ROM. FIGUEIREDO, E.A.P.; SCHMIDT, G.S.; LEDUR, M.C.; AVILA, V.S.; BRUM, P.A.R.; FIORENTIN, L.; JAENISCH, F.R.F. Genetic gain in egg production and egg weight in White Leghorn Embrapa 011. In: WORLD CONFERENCE ON ANIMAL PRODUCTION, 9.; REUNIÃO DA ASSOC. LATINOAMERICANA DE PRODUÇÃO ANIMAL, 18. Porto Alegre, 2003. Porto Alegre: WAAP; ALPA; SBZ; UFRGS, 2003b. CD-ROM. 
GREEN, P.; FALLS, K.; CROOKS, S. Documentation for CRIMAP, version 2.4. St. Louis: Washington University School of Medicine, 1990.

GROENEN, M.A.M.; CROOIJMANS, R.P.M.A.; VEENENDAAL, A.; CHENG, H.H.; SIWEK, M.; VAN DER POEL, J.J. A comprehensive microsatellite linkage map of the chicken genome. Genomics, v.49, p.265-274, 1998.

GROENEN, M.A.M.; CHENG, H.H.; BUMSTEAD, N.; BENKEL, B.F.; BRILES, W.E.; BURKE, T.; BURT, D.W.; CRITTENDEN, L.B.; DODGSON, J.; HILLEL, J.; LAMONT, S.; PONCE DE LEON, A.; SOLLER, M.; TAKAHASHI, H.; VIGNAL, A. A consensus linkage map of the chicken genome. Genome Research, v.10, p.137-147, 2000.

LEVIN, I.; SANTAGELO, L.; CHENG, H.; CRITTENDEN, L.B.; DODGSEN, J.B. An autosomal genetic linkage map of the chicken. Journal of Heredity, v.85, p.79-85, 1994.

SCHMID, M.; NANDA, I.; GUTTENBACH, M.; STEINLEIN, C.; HOEHN, H.; SCHARTL, M.; HAAF, T.; WEIGEND, S.; FRIES, R.; BUERSTEDDE, J-M.; WIMMERS, K.; BURT, D.W.; SMITH, J.; A'HARA, S.; LAW, A.; GRIFFIN, D.K.; BUMSTEAD, N.; KAUFMAN, J.; THOMPSON, P.A.; BURKE, T.A.; GROENEN, M.A.M.; CROOIJMANS, R.P.M.A.; VIGNAL, A.; FILLON, V.; MORRISON, M.; PITEL, F.; TIXIER-BOICHARD, M.; LADJALI-MOHAMMEDI, K.; HILLEL, J.; MAKI-TANILA, A.; CHENG, H.H.; DELANY, M.E.; BURNSIDE, J.; MIZUNO, S. First report on chicken genes and chromosomes 2000. Cytogenetics and Cell Genetics, v.90, p.169-218, 2000 .
VAN KAAM, J.B.C.H.M.; VAN ARENDONK, J.A.M.; GROENEN, M.A.M.; BOVENHUIS, H.; VEREIJKEN, A.L.J.; CROOIJMANS, R.P.M.A.; VAN DER POEL, J.J.; VEENENDAAL, A. Whole genome scan for quantitative trait loci affecting body weight in chickens using a three generation design. Livestock Production Science, v.54, p.133150,1998

VOORRIPS, E.R. MapChart: software for the graphical presentation of linkage maps and QTLs. The Journal of Heredity, v.93, p.1-2, 2002.

Received July 02, 2004

Accepted December 13, 2004 